\title{
PENGARUH STRUKTUR KEPEMILIKAN MANAJERIAL, STRUKTUR KEPEMILIKAN INSTITUSIONAL, SET KESEMPATAN INVESTASI, UKURAN PERUSAHAAN TERHADAP NILAI PERUSAHAAN
}

\author{
JURNAL ILMIAH
}

Untuk memenuhi sebagian persyaratan mencapai Gelar Magister pada Program Studi Magister Akuntansi

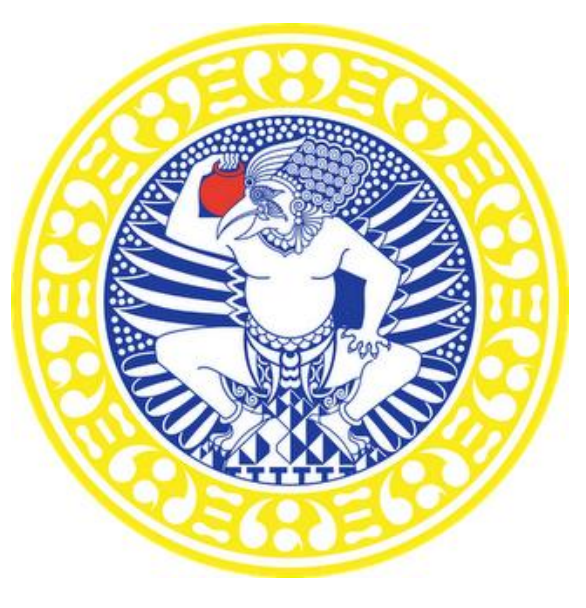

OLEH :

PURWO ADI NUGROHO

041142053

DOSEN PEMBIMBING

PROF. DR. SOEGENG SOETEDJO, S.E., Ak NIP. 194711271978021001

Program Studi Magister Akuntansi

Pascasarjana Fakultas Ekonomi dan Bisnis Universitas Airlangga 2014 
Jurnal ini telah disetujui

Surabaya, 2014

Dosen Pembimbing

Prof. Dr. Soegeng Soetedjo, S.E., Ak NIP. 194711271978021001 


\title{
PENGARUH STRUKTUR KEPEMILIKAN MANAJERIAL, STRUKTUR KEPEMILIKAN INSTITUSIONAL, SET KESEMPATAN INVESTASI, UKURAN PERUSAHAAN TERHADAP NILAI PERUSAHAAN
}

\begin{abstract}
The main purpose of this study was to determine the effect of managerial ownership structure, institutional ownership structure, investment opportunity set and firm size on firm value. The population of this study is a real estate company that listed on the Indonesia Stock Exchange with the observation period 2008 to 2012. Data obtained by the method of purposive sampling and the 42 companies sampled each year. The method of analysis used is multiple linear regression by using SPSS 20.0. The results of this study indicate that: (1) managerial ownership structure has no effect on firm value, (2) institutional ownership structure has significant effect on firm value, (3) investment opportunity set has significant effect on firm value, and (4) firm size has significant effect on firm value.
\end{abstract}

Key words: managerial ownership structure, institutional ownership structure, investment opportunity set, firm size and firm value

\section{PENDAHULUAN}

Tujuan utama perusahaan, terutama perusahaan yang berorientasi bisnis, adalah mengoptimalkan nilai perusahaan. Nilai perusahaan yang meningkat merupakan harapan bagi para pemegang saham karena peningkatan nilai perusahaan menunjukkan peningkatan kemakmuran pemegang saham (Bringham dan Houston, 2001:16). Meningkatnya nilai perusahaan juga akan meningkatkan minat investor untuk menanamkan modalnya pada suatu perusahaan karena diindikasikan perusahaan tersebut akan mempunyai prospek bagus di kemudian hari dan mendatangkan return saham yang tinggi. Nilai perusahaan tercermin pada harga saham perusahaan yang meningkat. Kinerja manajer perusahaan juga diukur dari ada tidaknya peningkatan nilai perusahaan yang mereka kelola.

Menurut Maurice, Thomas dalam Husnan dan Pudjiastuti (2004), nilai perusahaan adalah harga yang bersedia dibayar oleh calon pembeli (investor) seandainya pada suatu saat perusahaan tersebut dijual. Bagi perusahaan yang menerbitkan saham di pasar modal, harga yang diperjualbelikan di bursa 
merupakan indikator nilai perusahaan. Harga saham perusahaan dapat dijadikan sebagai pengukur nilai perusahaan karena harga saham pasar dapat memberikan nilai kemakmuran atau keuntungan bagi pemegang saham secara maksimum jika harga saham perusahaan meningkat.

Semakin tinggi harga saham, maka makin tinggi keuntungan pemegang saham sehingga keadaan ini akan diminati oleH investor karena dengan permintaan saham yang meningkatkan menyebabkan nilai perusahaan juga akan meningkat. Semakin tinggi nilai perusahaan, maka semakin besar kemakmuran yang akan diterima oleh pemilik perusahaan. Fakhrudin dan Sopian (2001) juga menyatakan bahwa nilai perusahaan akan meningkat apabila harga saham perusahaan meningkat. Nilai perusahaan diukur dari nilai pasar wajar dari harga saham dibandingkan dengan nilai buku harga saham perusahaan. Bagi perusahaan yang sudah go public, maka nilai pasar wajar perusahaan ditentukan mekanisme permintaan dan penawaran di bursa, yang tercermin dalam listing price.

Pihak manajemen perusahaan seringkali mempunyai tujuan dan kepentingan lain yang bertentangan dengan tujuan utama perusahaan dan sering mengabaikan kepentingan pemegang saham. Konflik tersebut terjadi karena manajer mengutamakan kepentingan pribadi, sebaliknya pemegang saham tidak menyukai kepentingan pribadi dari manajer karena akan menyebabkan penurunan keuntungan perusahaan dan berpengaruh terhadap harga saham sehingga menurunkan nilai perusahaan (Jensen dan Meckling, 1976).

Salah satu cara untuk meredam konflik kepentingan antara manajer dan pemegang saham dan juga dapat meningkatkan nilai perusahaan adalah adanya struktur kepemilikan saham oleh pihak institusional serta struktur kepemilikan saham oleh pihak manajerial perusahaan. Pihak institusional yang dimaksud adalah perusahaan asuransi, perusahaan perbankan, dan lain-lain.

Semakin tinggi kepemilikan institusional maka akan mengurangi perilaku opportunistic manajer yang dapat mengurangi agency cost yang diharapkan akan meningkatkan nilai perusahaan (Kusuma dan Hermuningsih, 2011). Struktur kepemilikan lain yaitu stuktur kepemilikan saham manajerial. Kepemilikan saham manajerial adalah proporsi saham biasa yang dimiliki oleh para manajemen. 
Dengan meningkatkan kepemilikan saham oleh manajemen akan mensejajarkan kedudukan manajer dengan pemegang saham sehingga manajemen akan termotivasi untuk berkinerja dengan baik hingga pada akhirnya dapat meningkatkan nilai perusahaan. Hasil penelitian Shleifer dan Vishny (1997) menemukan bahwa dalam kepemilikan saham manajerial yang rendah, maka insentif terhadap kemungkinan terjadinya perilaku oportunistik manajer akan meningkat.

Bagi investor, pertumbuhan perusahaan merupakan suatu prospek yang menguntungkan dan dicari, karena investasi yang ditanamkan diharapkan akan memberikan return yang tinggi di masa yang akan datang. Menurut Smith dan Watts (1992), peluang pertumbuhan perusahaan terlihat pada kesempatan investasi yang diproksikan dengan berbagai macam nilai set kesempatan investasi (IOS: investment opportunity set), set kesempatan investasi menunjukkan investasi perusahaan atau opsi pertumbuhan.

Nilai perusahaan juga seringkali dikaitan dengan ukuran suatu perusahaan tersebut. Perusahaan yang berukuran besar seringkali dinilai oleh masyarakat dan calon investor mempunyai nilai perusahaan yang baik, begitu pula sebaliknya. Dalam penelitian ini akan diuji apakah ukuran perusahaan berpengaruh terhadap nilai perusahaan.

Alfred Nainggolan, Kepala Riset PT Buana Capital Indonesia memperkirakan, pertumbuhan emiten properti mencapai $30-40 \%$ per tahun. Angka tersebut lebih tinggi dibandingkan sektor perbankan sebagai sektor yang profitable yang pertumbuhan labanya berkisar antara 20-25\% (www.pasarmodal.inilah.com, 2013).

Pemilihan sampel properti tersebut didasari karena peneliti mengindikasikan perusahan properti mempunyai nilai perusahaan yang tinggi, hal ini dikarenakan saham perusahaan properti termasuk jajaran saham pilihan karena 12 dari 52 perusahaan properti (terdapat dalam lampiran 1), atau sekitar 23,08\%, masuk ke dalam daftar saham perusahaan paling aktif dan diburu oleh investor (LQ45).

Adapun rumusan masalah dalam penelitian ini adalah sebagai berikut: 
(1) Apakah struktur kepemilikan manajerial berpengaruh terhadap nilai perusahaan?

(2) Apakah struktur kepemilikan institusional berpengaruh terhadap nilai perusahaan?

(3) Apakah set kesempatan investasi berpengaruh terhadap nilai perusahaan?

(4) Apakah ukuran perusahaan berpengaruh terhadap nilai perusahaan?

\section{KAJIAN TEORI}

Teori keagenan (agency theory) menjelaskan bahwa hubungan agensi muncul satu orang atau lebih (principal) mempekerjakan orang lain (agen) untuk memberikan suatu jasa dan kemudian mendelegasikan wewenang pengambilan keputusan kepada agen tersebut (Jensen dan Meckling, 1976). Jensen dan Meckling (1976) juga menyatakan bahwa dalam Teori keagenan (agency theory) terdapat suatu karakteristik hubungan keagenan yang dapat didefinisikan sebagai suatu kontrak dimana satu pihak (prinsipal) mempekerjakan pihak lain (agen) untuk melakukan beberapa pekerjaan atas nama prinsipal.

Manajemen merupakan pihak yang dikontrak oleh pemegang saham untuk bekerja demi kepentingan pemegang saham. Untuk itu manajemen diberikan sebagian kekuasaan untuk membuat keputusan bagi kepentingan terbaik pemegang saham. Oleh karena itu, manajemen wajib mempertanggungjawabkan semua upayanya kepada pemegang saham.

\section{HIPOTESIS}

Soliha dan Taswan (2002), Wahyudi dan Pawestri (2006), Sofyaningsih dan Hardiningsih (2011) dan Jensen dan Meckling (1976) meneliti bahwa struktur kepemilikan manajerial berpengaruh terhadap nilai perusahaan. Murwaningsari (2008), Sujoko dan Soebiantoro (2007), Siallagan dan Machfoedz (2006) dan Animah dan Ramadhani (2009) mengungkapkan bahwa tidak ada pengaruh kepemilikan manajerial terhadap nilai perusahaan. 
Shleifer dan Vishny (1986) dan Bathala et al (1994), Sujoko dan Soebiantoro (2007) dan Rahmawati dan Triatmoko (2007) meneliti bahwa struktur kepemilikan institusional berpengaruh terhadap nilai perusahaan. Akan tetapi berdasarkan penelitian dari Animah dan Ramadhani (2009), Wahyudi dan Pawestri (2006), Sofyaningsih dan Hardiningsih (2011) kepemilikan institusional tidak berpengaruh terhadap nilai perusahaan.

Penelitian lain dilakukan oleh Chen et.al. (2000) dan Hasnawati (2005), Rachmawati dan Triatmoko (2007), melakukan penelitian untuk menjelaskan pengaruh set kesempatan investasi terhadap nilai perusahaan.

Soliha dan Taswan (2002), Sujoko dan Soebiantoro (2007) dan Animah dan Ramadhani (2009) menyatakan bahwa ukuran perusahaan berpengaruh terhadap nilai perusahaan. Dewi dan Wirajaya (2013) menyatakan bahwa ukuran perusahaan tidak berpengaruh terhadap nilai perusahaan.

Dari uraian di atas, maka hipotesis yang diuji dalam penelitian ini adalah sebagai berikut

$\mathrm{H}_{1}$ : struktur kepemilikan manajerial, struktur kepemilikan institutional, set kesempatan investasi, ukuran perusahaan berpengaruh terhadap nilai perusahaan

\section{METODOLOGI}

Variabel dependen (terikat) yang digunakan dalam penelitian ini adalah nilai perusahaan. Variabel independen (bebas) dalam penelitian ini adalah struktur kepemilikan manajerial, struktur kepemilikan institusional, set kesempatan investasi dan ukuran perusahaan.

Populasi dalam penelitian ini yakni seluruh perusahaan properti yang go public yang terdaftar di Bursa Efek Indonesia dari tahun 2008-2012. Sampel penelitian ini yakni perusahaan properti go public berturut-turut di Bursa Efek Indonesia mulai dari 2008-2012. Periode pengamatan yang dilakukan adalah untuk jangka waktu 5 tahun, yaitu tahun 2008-2012, agar kondisi sampel relevan dengan keadaan sekarang. 
Tabel 1 Sampel Penelitian

\begin{tabular}{|l|c|}
\hline $\begin{array}{l}\text { Perusahaan properti yang go public antara } \\
\text { tahun 2008-2012 }\end{array}$ & 52 \\
\hline $\begin{array}{l}\text { Perusahaan yang tidak menerbitkan laporan } \\
\text { keuangan berturut-turut antara 2008-2012 }\end{array}$ & $(10)$ \\
\hline Jumlah sampel per tahun & 42 \\
\hline
\end{tabular}

Sumber: Data yang diolah

\section{Teknik Analisis}

Model yang digunakan untuk menguji pengaruh variabel-variabel secara spesifik terhadap nilai perusahaan dalam penelitian ini dinyatakan dalam persamaan regresi di bawah ini:

$$
\mathbf{Y}=\alpha+\beta 1 \mathrm{KM}+\beta 2 \mathrm{KI}+\beta 3 \mathrm{SKI}+\beta 4 \mathrm{UP}+\mathrm{e}
$$

Keterangan:

$\mathrm{Y}=$ Nilai Perusahaan

$\alpha=$ Konstanta

$\beta 1-\beta 5=$ Koefisien Regresi

$\mathrm{KM}=$ Kepemilikan Manajemen

$\mathrm{KI}=$ Kepemilikan Instutional

$\mathrm{SKI}=$ Set Kesempatan Investasi

UP = Ukuran Perusahaan

$\mathrm{e}=$ Error Term

\section{HASIL DAN PEMBAHASAN}

Pengukuran koefisien determinasi dilakukan untuk mengetahui persentase pengaruh variabel independen terhadap perubahan variabel dependen. Dari angka ini akan diketahui seberapa besar variabel dependen mampu dijelaskan oleh variabel independennya, sedangkan sisanya dijelaskan oleh sebab-sebab lain diluar model. 
Tabel 2.

Koefisien Determinasi $\left(\mathrm{R}^{2}\right)$

\begin{tabular}{|l|c|r|r|c|}
\multicolumn{1}{|c|}{} & & & Model Summary \\
Model & $\mathrm{R}$ & $\mathrm{R}$ Square & $\begin{array}{c}\text { Adjusted R } \\
\text { Square }\end{array}$ & $\begin{array}{c}\text { Std. Error } \\
\text { of the } \\
\text { Estimate }\end{array}$ \\
\hline 1 & $.653^{\mathrm{a}}$ & .427 & .416 & .81956 \\
\hline
\end{tabular}

a. Predictors: (Constant), UP, KI, SKI, KM

b. Dependent Variable: NP

Angka koefisien $\mathrm{R}^{2}$ dalam Tabel 2 adalah sebesar 0.416, yang menujukkan bahwa variabel dependen dalam penelitian ini yakni nilai perusahaan, dapat dijelaskan sebesar 0,416 atau 41,60\% oleh variabel independen dalam penelitian ini yakni struktur kepemilikan manajerial, struktur kepemilikan institusional, set kesempatan investasi dan ukuran perusahaan sedangkan sisanya sebesar 58,40\% akan dijelaskan oleh variabel independen lain diluar variabel independen dalam penelitian ini.

\section{Uji Hipotesis}

Hipotesis yang akan diuji dalam penelitian ini yaitu pengujian pengaruh struktur kepemilikan manajerial, struktur kepemilikan institusional, set kesempatan investasi dan ukuran perusahaan terhadap nilai perusahaan. Model yang digunakan untuk menguji pengaruh variabel-variabel secara spesifik terhadap nilai perusahaan dalam penelitian ini dinyatakan dalam persamaan regresi di bawah ini:

$$
\mathrm{Y}=\alpha+\beta 1 \mathrm{KM}+\boldsymbol{\beta} 2 \mathrm{KI}+\boldsymbol{\beta} 3 \mathrm{SKI}+\boldsymbol{\beta} 4 \mathrm{UP}+\mathrm{e}
$$

Nilai koefisien standardized beta pada persamaan tersebut merupakan nilai persamaan pengujian penelitian ini. Bila nilai standardized beta pada persamaan tersebut positif dan signifikan $(\mathrm{p}<0,05)$, berarti struktur kepemilikan manajerial, struktur kepemilikan institusional, set kesempatan investasi dan ukuran perusahaan mempengaruhi nilai perusahaan. Hasil analisis regresi akan ditampilkan dalam Tabel 3 berikut. 
Tabel 3.

Uji Parsial

Coefficients $^{\mathrm{a}}$

\begin{tabular}{|c|c|c|c|c|c|c|}
\hline & & \multicolumn{2}{|c|}{$\begin{array}{c}\text { Unstandardized } \\
\text { Coefficients } \\
\end{array}$} & \multirow{2}{*}{$\begin{array}{c}\begin{array}{c}\text { Standardized } \\
\text { Coefficients }\end{array} \\
\text { Beta } \\
\end{array}$} & \multirow[b]{2}{*}{$\mathrm{t}$} & \multirow[b]{2}{*}{ Sig. } \\
\hline \multicolumn{2}{|c|}{ Model } & B & Std. Error & & & \\
\hline \multirow[t]{5}{*}{1} & (Constant) & -5.612 & 1.540 & & -3.643 & .000 \\
\hline & $\mathrm{KM}$ & .007 & .009 & .046 & .764 & .446 \\
\hline & KI & .007 & .003 & .130 & 2.135 & .034 \\
\hline & SKI & .803 & .083 & .555 & 9.679 & .000 \\
\hline & UP & .384 & .121 & .205 & 3.188 & .002 \\
\hline
\end{tabular}

a. Dependent Variable: nilai

Berdasarkan Tabel 3 di atas, persamaan koefisien standardized beta dalam penelitian ini adalah sebagai berikut :

$$
\mathrm{Y}=-\mathbf{5 . 6 1 2}+\mathbf{0 . 0 0 7} \mathrm{KM}+\mathbf{0 . 0 0 7} \mathrm{KI}+\mathbf{0 . 8 0 3} \mathrm{SKI}+\mathbf{0 . 3 8 4} \mathrm{UP}+\mathrm{e}
$$

Konstanta sebesar -5.612 menyatakan bahwa jika tidak memperhitungkan struktur kepemilikan manajerial, struktur kepemilikan institusional, set kesempatan investasi dan ukuran perusahaan maka kemungkinan nilai perusahaan sampel adalah sebesar -5.612.

\section{Pengujian secara Parsial (Uji Statistik T)}

Dalam pengujian secara parsial, jika $\mathrm{T}$ hitung lebih besar dari $\mathrm{T}$ tabel, maka variabel independen secara individu berpengaruh terhadap variabel dependen, artinya hipotesis diterima. Pada Tabel 3 akan diketahui besarnya $\mathrm{T}$ hitung dan melihat $\mathrm{T}$ tabel untuk 210 sampel yakni df $210=1,65211$, maka jika masing-masing $\mathrm{T}$ hitung lebih besar daripada 1,652 maka hipotesis diterima :

a. Hasil T hitung pada kepemilikan manajerial sebesar $0,764<1,652$, hal ini berarti kepemilikan manajerial tidak mempengaruhi nilai perusahaan.

b. Hasil T hitung pada kepemilikan institusional yakni sebesar 2,135 > 1,652 yang berarti kepemilikan institusional berpengaruh positif signifikan dengan nilai signifikansi sebesar 0,034 dimana lebih kecil dari 0,05. 
c. Hasil T hitung pada set kesempatan investasi sebesar 9,679 > 1,652 yang berarti set kesempatam investasi berpengaruh positif terhadap nilai perusahaan. Nilai signifikansi lebih kecil dari 5\% yakni sebesar 0.000 yang berarti set kesempatan investasi berpengaruh signifikan terhadap nilai perusahaan.

d. Hasil T hitung pada ukuran perusahaan sebesar 3,188 > 1,652, yang berarti ukuran perusahaan berpengaruh positif terhadap nilai perusahaan. Nilai signifikansi lebih kecil dari 5\% yakni sebesar 0.002 yang berarti ukuran perusahaan berpengaruh signifikan terhadap nilai perusahaan.

\section{Pengujian secara Simultan (Uji Statistik F)}

Dalam pengujian simultan, apabila nilai $\mathrm{F}$ hitung lebih besar dari pada $\mathrm{F}$ table, maka dapat disimpulkan bahwa semua variabel independen (struktur kepemilikan manajerial, struktur kepemilikan institusional, set kesempatan investasi dan ukuran perusahaan) secara simultan berpengaruh terhadap nilai perusahaan.

Tabel 4.

Uji Simultan

ANOVA $^{b}$

\begin{tabular}{|rr|r|r|r|r|r|}
\hline Model & Sum of Squares & df & Mean Square & F & Sig. \\
\hline 1 & Regression & 102.538 & 4 & 25.634 & 38.165 & $.000^{\mathrm{a}}$ \\
& 137.694 & 205 & .672 & & \\
Residual & 240.232 & 209 & & & \\
Total & & & & \\
\hline
\end{tabular}

a. Predictors: (Constant), UP, KI, SKI, KM

b. Dependent Variable: NP

Dalam tabel 4, variabel independen penelitian berupa struktur kepemilikan manajerial, struktur kepemilikan institusional, set kesempatan investasi dan ukuran perusahaan secara simultan berpengaruh signifikan terhadap nilai perusahaan, hal ini terlihat dari nilai $\mathrm{F}$ hitung $>\mathrm{F}$ tabel, yakni $\mathrm{F}$ hitung sebesar 38,165 sedangkan $\mathrm{F}$ tabel hanya sebesar 2,4154 dan nilai signifikansi uji simultan adalah sebesar 0,000 yang lebih besar dari $\alpha=0,05$. 


\section{Pengaruh Kepemilikan Manajerial terhadap Nilai Perusahaan}

Kepemilikan manajerial tidak mempunyai pengaruh terhadap nilai perusahaan. Hal ini dapat dilihat dari hasil T Statistik 0,764 $<\mathrm{T}$ Hitung 1,652, yang berarti kepemilikan manajerial tidak mempunyai nilai perusahaan. Dengan demikian hipotesis yang menyatakan bahwa kepemilikan manajerial berpengaruh terhadap nilai perusahaan tidak diterima. Hasil ini sejalan dengan penelitian Murwaningsari (2008), Sujoko dan Soebiantoro (2007) namun tidak sejalan dengan hasil penelitian Soliha dan Taswan (2002), Wahyudi dan Pawestri (2006), Sofyaningsih dan Hardiningsih (2011) dan Jensen dan Meckling (1976).

Kepemilikan manajerial tidak berpengaruh signifikan terhadap nilai perusahaan disebabkan karena rendahnya saham yang dimiliki oleh manajemen yaitu sebesar 1,79\%, hal ini mengakibatkan pihak manajemen belum merasa ikut memiliki perusahaan, karena tidak semua keuntungan yang didapat perusahaan dapat dinikmati oleh manajemen. Hal ini menyebabkan pihak manajemen kurang termotivasi untuk memaksimalkan utilitasnya sehingga merugikan pemegang saham. Selain itu dengan rendahnya kepemilikan saham oleh manajemen membuat kinerja manajemen juga cenderung rendah sehingga tidak mempengaruhi nilai perusahaan. Dengan demikian, kepemilikan manajemen belum mampu menjadi mekanisme untuk meningkatkan nilai perusahaan.

Menurut Animah dan Ramadhani (2009), tingkat kepemilikan manajerial tidak akan mempengaruhi opini publik tentang nilai suatu perusahaan. Jumlah kepemilikan yang masih kecil ini membuat manajer perusahaan lebih banyak dikendalikan pemilik mayoritas sehingga manajer hanya sebagai kepanjangan tangan pemilik mayoritas. (Sujoko dan Soebiantoro, 2007).

\section{Pengaruh Kepemilikan Institusional terhadap Nilai Perusahaan}

Kepemilikan institusional berpengaruh terhadap nilai perusahaan. Hasil T hitung kepemilikan institusional lebih besar daripada $\mathrm{T}$ tabel sebesar 2,135 > 1,652. Dengan demikian, hipotesis yang menyatakan bahwa kepemilikan institusional berpengaruh positif terhadap nilai perusahaan diterima. 
Hasil penelitian ini juga mendukung hasil penelitian yang dilakukan oleh Shleifer dan Vishny (1986) dan Bathala et al (1994), Sujoko dan Soebiantoro (2007) dan Rahmawati dan Triatmoko (2007) dimana semakin besar presentase saham yang dimiliki oleh investor institusional akan menyebabkan usaha monitoring menjadi semakin efektif, dan selanjutnya akan meningkatkan nilai atau kinerja perusahaan karena dapat mengendalikan perilaku oportunistik manajer dan memaksa manajer untuk mengurangi tingkat hutang secara optimal, sehingga akan mengurangi agency cost. Semakin besar kepemilikan institusional maka semakin efisien juga pemanfaatan aktiva perusahaan dan diharapkan juga dapat bertindak sebagai pencegahan terhadap pemborosan dan manipulasi laba yang dilakukan oleh manajemen sehingga akan meningkatkan nilai perusahaan.

Pendapat ini didukung oleh bukti empiris yang ditemukan oleh Holderness (1988), Masdupi (2005), Sujoko dan Soebiantoro (2007) yang menemukan pengaruh positif-signifikan tingkat kepemilikan institusional dalam jumlah yang cukup besar terhadap nilai perusahaan. Namun hasil penelitian ini tidak sejalan dengan penelitian Animah dan Ramadhani (2009), Wahyudi dan Pawestri (2006), Sofyaningsih dan Hardiningsih (2011).

\section{Pengaruh Set Kesempatan Investasi terhadap Nilai Perusahaan}

Set kesempatan investasi tidak berpengaruh terhadap nilai perusahaan. Hasil $\mathrm{T}$ hitung pada set kesempatan investasi adalah sebesar 9,679 > 1,652. Dengan demikian, hipotesis kedua dalam penelitian ini diterima. Hal ini tidak mendukung penelitian dari

Investor percaya bahwa perusahaan yang meningkatkan set kesempatan investasi nya, akan memiliki prospek yang bagus di kemudian hari, sehingga berinvestasi pada saham perusahaan tersebut akan menghasilkan return yang lebih tinggi. Penelitian ini mendukung signaling theory, yang menyatakan bahwa pengeluaran investasi memberikan sinyal positif mengenai pertumbuhan perusahaan di masa yang akan datang, sehingga dapat meningkatkan harga saham yang digunakan sebagai indikator nilai perusahaan (Wahyudi dan Pawestri, 2006). Keputusan investasi yang dilakukan suatu perusahaan mengandung informasi 
yang berisi sinyal-sinyal akan prospek perusahaan. Kepercayaan investor terhadap perusahaan properti yang memiliki keputusan investasi tinggi pada saat ini, menyebabkan naiknya permintaan terhadap saham perusahaan properti di Indonesia. Hasil penelitian ini mendukung Chen et.al. (2000), Hasnawati (2005), Rachmawati dan Triatmoko (2007), yang memperoleh hasil penelitian bahwa set kesempatan investasi memiliki pengaruh positif secra signifikan terhadap nilai perusahaan.

\section{Pengaruh Ukuran Perusahaan terhadap Nilai Perusahaan}

Ukuran perusahaan berpengaruh positif terhadap nilai perusahaan. Hasil T hitung pada ukuran perusahaan sebesar 3,188 > 1,652. Nilai signifikansi lebih kecil dari 5\% yakni sebesar 0.002 yang berarti ukuran perusahaan berpengaruh signifikan terhadap nilai perusahaan.

Dengan demikian, hipotesis dalam penelitian ini yakni ukuran perusahaan berpengaruh signifikan terhadap nilai perusahaan diterima. Hal ini mendukung penelitian dari Soliha dan Taswan (2002), Sujoko dan Soebiantoro (2007) dan Animah dan Ramadhani (2009). Hal ini bertentangan dengan penelitian dari Dewi dan Wirajaya (2013) menyatakan bahwa ukuran perusahaan tidak berpengaruh terhadap nilai perusahaan.

Perusahaan dengan ukuran yang lebih besar memiliki akses yang lebih mudah untuk mendapat sumber pendanaan dari pihak ketiga, karena perusahaan dengan ukuran besar memiliki total aset lebih besar yang dapat dijaminkan daripada perusahaan dengan ukuran lebih kecil. Ukuran perusahaan dapat menyebabkan suatu perusahaan mempunyai nilai lebih (Animah dan Ramadhani, 2009).

Hasil penelitian Sujoko dan Soebiantoro (2007) membuktikan bahwa ukuran perusahaan berpengaruh positif terhadap nilai perusahaan. Adanya pengaruh positif mengindikasikan bahwa perusahaan-perusahaan besar cenderung memberikan hasil operasi yang lebih besar sehingga memiliki kemampuan yang lebih besar untuk meberikan imbal balik investasi yang lebih menguntungkan dibandingkan dengn perusahaan-perusahaan kecil. 


\section{SIMPULAN}

Penelitian ini menguji pengaruh dari kepemilikan manajerial, kepemilikan institusional, set kesempatan investasi dan ukuran perusahaan terhadap nilai perusahaan. Dari empat hipotesis yang dibangun, tiga hipotesis diterima, dan satu hipotesis ditolak. Disimpulkan bahwa :

1. Kepemilikan manajerial tidak berpengaruh terhadap nilai perusahaan.

2. Kepemilikan institusional berpengaruh signifikan terhadap nilai perusahaan.

3. Set kesempatan investasi berpengaruh signifikan terhadap nilai perusahaan.

4. Ukuran perusahaan berpengaruh signifikan terhadap nilai perusahaan.

\section{SARAN}

Penelitian selanjutnya dapat memperluas sampel ke sektor industri lain, dan mempergunakan rentang waktu pengambilan sampel yang lebih panjang dan penelitian selanjutnya juga menggunakan informasi internal lainnya seperti rasio keuangan lain (return on equity, dividend per share) dan informasi eksternal perusahaan yang menyangkut kondisi makro ekonomi misalnya seperti keadaan pasar modal, suku bunga dan lain-lain. Selain itu untuk penelitian selanjutnya dapat pula menggunakan model lain dalam menghitung nilai perusahaan.

\section{REFERENSI}

Animah., dan Ramadhani, S., 2009, Pengaruh Struktur Kepemilikan, Mekanisme Corporate Governance dan Ukuran Perusahaan Terhadap Nilai Perusahaan. Jurnal MAKSI.

Bathala., CT, Moon., KP, Rao., RP, 1994, Managerial Ownership, Debt Policy, and The Impact of Institutional Holding: An Agency Perspective. Financial Management, Vol. 23 No 3 pp. 38-50.

Bringham, E. F dan Houston., 2001, Manajemen Keuangan. Jakarta: Salemba Empat, Edisi kedelapan.

Chen, S.S., K.W. Ho, C.F. Lee dan G.H.H. yeo, 2000, Investment opportunity, Free cash Flow and Market Reaction to International Joint Venture, Journal of Banking and Finance, Vol. 24:1747-1765. 
Christiawan, Y.J., dan Tarigan., 2007, Kepemilikan Manajerial: Kebijakan Hutang, Kinerja, dan Nilai Perusahaan. Jurnal Akuntansi dan Keuangan. Vol. 9, No. 1, Mei: 1-8.

Dewi, A., dan Wirajaya., 2013, Pengaruh Struktur Modal, Profitabilitas dan Ukuran Perusahaan terhadap Nilai Perusahaan. E-Jurnal Akuntansi Udayana. Hal 358-372.

Erlina, Sri Mulyani, 2007. Metodologi Penelitian Bisnis : Untuk Akuntansi dan Manajemen, Cetakan Pertama USU Press, Medan.

Fakhruddin, M dan HM. Sopian. 2001. Perangkat dan Model Analisis Investasi di Pasar Modal. Buku 1. Jakarta: Elex Media Komputindo.

Gaver, Jennifer J., and Gaver. 1993. Additional Evidence on The Association Between The Investment Opportunity Set an Corporate Financing, Dividend, and Compensation Policies. Journal of Accounting and Economics, Vol. 16, pp. 125-160.

Ghozali, I., 2001. Aplikasi Analisis Multivariate dengan Program SPSS. Semarang: Badan Penerbit Universitas Diponegoro.

Handayani, C., 2007, Analisis Pengaruh Proporsi Kepemilikan Saham terhadap Kebijakan Pendanaan dalam Meningkatkan Kinerja Perusahaan, Tesis, Semarang: Program Studi Magister Manajemen Universitas Diponegoro. http://eprints.undip.ac.id/15442/

Harjito, D.A., dan Nurfauziah., 2006, Hubungan Kebijakan Hutang, Insider Ownership dan Kebijakan Dividen dalam Mekanisme Pengawasan Masalah Agensi di Indonesia, Jurnal Akuntansi dan Auditing Indonesia, Vol. 10, No. 2, Desember: 121-136.

Hasnawati, S. 2005. Implikasi Keputusan Investasi, Pendanaan, dan Deviden Terhadap Nilai Perusahaan Publik di Bursa Efek Jakarta. Usahawan: No. 09/Th XXXIX. September 2005: 33-41.

Holderness, C.G., dan Sheehan, D.P. 1988. The Role of Majority Shareholders in Publicly Held Corporations: An exploratory analysis. Journal of Financial Economics, 20, pp.317-40.

Husnan, S., dan Pudjiastuti., 2004, Dasar-Dasar Manajemen Keuangan, Edisi Keempat, Yogyakarta: UPP AMP YKPN.

Jensen, M., dan Meckling., 1976, Theory of the Firm: Managerial Behavior, Agency Cost and Ownership Structure. Journal of financial Economics. PP 305-360 . 
Kallapur, Sanjay, and Mark. A. T., 2001. The Investment Opportunity Set determinants, consequences and measurement. Managerial Finance, Vol. 27, No. 3 .

Keown, K., M. Petty dan Scott., 2004. Manajemen Keuangan 1 dan 2. Edisi 9 (terjemahan). Jakarta: Indeks.

Kusuma, D., dan Hermuningsih, S., 2011. Pengaruh Struktur Kepemilikan Terhadap Nilai Perusahaan Dengan Kinerja Keuangan dan Kebijakan Hutang Sebagai Variabel Intervening. Jurnal Siasat Bisnis. Vol. 15, No 1, Januari: 27-36.

Mardiyah, A., dan Indriantoro., 2001, Pengaruh Variabel Akuntansi Dan Data Pasar Terhadap Resiko Persepsian (Perceived Risk) saham pada perusahaan publik yang terdaftar di BEJ. Jurnal Riset Akuntansi Indonesia, Vol 4, No 3: 277-302.

Masdupi, E., 2005, Analisis Dampak Struktur Kepemilikan pada Kebijakan Hutang dalam Mengontrol Konflik Keagenan, Jurnal Ekonomi dan Bisnis Indonesia, Vol. 20, No. 1, Januari: 57-69.

Murhadi, W., 2008, Pengaruh Tahapan Daur Hidup Perusahaan, Good Corporate Governance, Set Kesempatan Investasi, Alira Kas Bebas dan Struktur Kepemilikan Terhadap Nilai Perusahaan: Tinjauan Teoritis. Majalah Ilmiah Fakultas Ekonomi Unpar, Vol 12, No.2.

Murwaningsari, E., 2008, Pengaruh Corporate Governance Terhadap Nilai Perusahaan dengan Manajemen Laba Sebagai Variabel Intervening. Jurnal Riset Akuntansi Indonesia, Vol. 13, No. 2, November.

Myers, S.C, 1977, Determinant of Corporate Borrowing, Journal of Financial Economics, Vol. 5: 147 -175.

Prabasari, Y dan Kusuma. H., 2005, Faktor-faktor yang Mempengaruhi Struktur Modal Perusahaan Manufaktur Go Public di Bursa Efek Jakarta. Jurnal Sinergi Edisi Khusus Keuangan hal 1-15.

Santoso, S., 2004, Buku Latihan SPSS Statistik Parametrik. Jakarta: PT. Elex Media Komputindo Kelompok Gramedia.

Shleifer, A. dan Vishny., 1997, A Survey of Corporate Governance. Journal of Finance, Vol 52, No 2, Juni: 737-783.

Sofyaningsih, S dan Hardiningsih, P., 2011, Struktur Kepemilikan, Kebijakan Dividen, Kebijakan Utang Dan Nilai Perusahaan Ownership Structure, 
Dividend Policy And Debt Policy And Firm Value. Dinamika Keuangan dan Perbankan, Vol 3 No 1, Mei: Hal 68-87.

Soliha, E., dan Taswan., 2002, Pengaruh Kebijakan Hutang terhadap Nilai Perusahaan serta Beberapa Faktor yang Mempengaruhinya, Jurnal Bisnis dan Ekonomi, Vol. 9, No. 2, September: 149-163.

Sudarmadji, A., dan Sularto, L., 2007, Pengaruh Ukuran Perusahaan, Profitabilitas, Leverage, dan Tipe Kepemilikan Perusahaan terhadap Luas Voluntary Disclosure Laporan Keuangan Tahunan, Jurnal PESAT. Jakarta : Universitas Gunadarma

Sujoko dan Soebiantoro, U., 2007, Pengaruh Struktur Kepemilikan Saham, Leverage Faktor Intern dan Faktor Ekstern terhadap Nilai Perusahaan (Studi Empirik pada Perusahaan Manufaktur dan Non Manufaktur di Bursa Efek Jakarta), Jurnal Manajemen dan Kewirausahaan, Vol. 9, No. 1, Maret: 41-48.

Smith Jr., Clifford W., and Ross L. W. 1992. The Investment Opportunity Set and Corporate Financing, Dividend an Compensation Policies. Journal of Financial Economics; 32, pp. 263-292

Utama, M., 2004. Komite Audit, Good Corporate Governance dan Pengungkapan Informasi. Jurnal Akuntansi dan Keuangan Indonesia. Vol 1, Hal 61-79.

Wahidahwati, 2002, Pengaruh Kepemilikan Manajerial dan Kepemilikan Institusional pada Kebijakan Hutang Perusahaan : Sebuah Perspektif Theory Agency, Jurnal Riset Akuntansi Indonesia, Vol. 5, No. 1, Januari: $1-16$. 